\title{
Front Matter: Volume 6414
}

, "Front Matter: Volume 6414," Proc. SPIE 6414, Smart Structures, Devices, and Systems III, 641401 (18 January 2007); doi: 10.1117/12.723916 SPIE. Event: SPIE Smart Materials, Nano- and Micro-Smart Systems, 2006, 


\title{
PROCEEDINGS OF SPIE
}

\section{Smart Structures, Devices, and Systems III}

\author{
Said F. Al-Sarawi \\ Chair/Editor

\section{1-13 December 2006 \\ Adelaide, Australia}

Sponsored and Published by

SPIE-The International Society for Optical Engineering

\section{Cosponsored by}

Australian Government Department of Defence, Defence Science and Technology

Organisation (Australia)

Office of Naval Research through the Global Office of Naval Research Science and

Technology (USA)

Air Force Office of Scientific Research through the Asian Office of Aerospace Research

and Development (USA and Japan)

COSNet-ARC Complex Open Systems Research Network (Australia)

Australian Research Council Nanotechnology Network (Australia)

Volume 6414

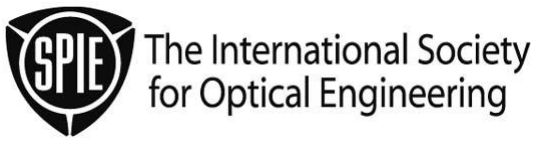

Proceedings of SPIE-The International Society for Optical Engineering 9780819465221, v. 6414

SPIE is an international technical society dedicated to advancing engineering and scientific applications of optical, photonic, imaging, electronic, and optoelectronic technologies. 
The papers included in this volume were part of the technical conference cited on the cover and title page. Papers were selected and subject to review by the editors and conference program committee. Some conference presentations may not be available for publication. The papers published in these proceedings reflect the work and thoughts of the authors and are published herein as submitted. The publisher is not responsible for the validity of the information or for any outcomes resulting from reliance thereon.

Disclaimer: The support provided for the conference by the co-sponsors is not intended as an endorsement of the contents of anything in these proceedings. Specifically, DSTO support is not intended to express or imply endorsement by the Australian Commonwealth Government; AFOSR/AOARD support is not intended to express or imply endorsement by the U.S. Federal Government; ONR Global support is not intended to express or imply endorsement by the U.S. Federal Government; COSNet support is not intended to express or imply endorsement by the Australian Research Council (ARC) or the Australian Commonwealth Government; ARC Nanotech Network support is not intended to express or imply endorsement by the Australian Research Council (ARC) or the Australian Commonwealth Government.

Please use the following format to cite material from this book:

Author(s), "Title of Paper," in Smart Structures, Devices, and Systems III, edited by Said F. Al-Sarawi, Proceedings of SPIE Vol. 6414 (SPIE, Bellingham, WA, 2007) Article CID Number.

ISSN 0277-786X

ISBN 9780819465221

Published by

SPIE-The International Society for Optical Engineering

P.O. Box 10, Bellingham, Washington 98227-0010 USA

Telephone 1 360/676-3290 (Pacific Time) · Fax 1 360/647-1445

http://www.spie.org

Copyright (@ 2007, The Society of Photo-Optical Instrumentation Engineers

Copying of material in this book for internal or personal use, or for the internal or personal use of specific clients, beyond the fair use provisions granted by the U.S. Copyright Law is authorized by SPIE subject to payment of copying fees. The Transactional Reporting Service base fee for this volume is $\$ 18.00$ per article (or portion thereof), which should be paid directly to the Copyright Clearance Center (CCC), 222 Rosewood Drive, Danvers, MA 01923. Payment may also be made electronically through CCC Online at http://www.copyright.com. Other copying for republication, resale, advertising or promotion, or any form of systematic or multiple reproduction of any material in this book is prohibited except with permission in writing from the publisher. The CCC fee code is 0277-786X/07/ $\$ 18.00$.

Printed in the United States of America. 


\title{
Contents
}

\author{
ix Conference Committee \\ Introduction \\ xiii Symposium Sponsors
}

\section{SESSION 1 ACTUATORS I}

641403 State estimation of nonlinear piezoelectric stack actuator hysteresis model [6414-02]

J. L. Minase, T.-F. Lu, F. Wornle, The Univ. of Adelaide (Australia)

\section{SESSION 2 RADIO FREQUENCY}

641405 TCAM core design in 3D IC for low matchline capacitance and low power (Invited Paper) [6414-05]

E. C. Oh, P. D. Franzon, North Carolina State Univ. (USA)

641406 A broadband 8-18GHz 4-input 4-output Butler matrix [6414-06]

L. Milner, M. Parker, Defence Science and Technology Organisation (Australia)

641407 An optimized low-power voltage controlled oscillator [6414-08]

K. Shah, H. P. Le, J. Singh, La Trobe Univ. (Australia)

641408 A high-frequency divider in 0.18 um SiGe BiCMOS technology [6414-09]

N. Kamal, Y. Zhu, L. T. Hall, S. F. Al-Sarawi, Univ. of Adelaide (Australia); C. Burnet, I. Holland, A. Khan, A. Pollok, J. Poyner, Univ. of South Australia (Australia); M. Boers, J. A. Howarth, A. Lauterbach, J. Harrison, Macquarie Univ. (Australia); J. Rathmell, The University of Sydney (Australia); M. Batty, A. Parker, L. M. Davis, Macquarie Univ. (Australia); W. G. Cowley, Univ. of South Australia (Australia); N. H. E. Weste, Univ. of Adelaide (Australia) and Univ. of South Australia (Australia); D. Abbott, Univ. of Adelaide (Australia)

Pagination: Proceedings of SPIE follow an e-First publication model, with papers published first online and then in print and on CD-ROM. Papers are published as they are submitted and meet publication criteria. A unique, consistent, permanent citation identifier (CID) number is assigned to each article at the time of the first publication. Utilization of CIDs allows articles to be fully citable as soon they are published online, and connects the same identifier to all online, print, and electronic versions of the publication.

SPIE uses a six-digit CID article numbering system in which:

- The first four digits correspond to the SPIE volume number.

- The last two digits indicate publication order within the volume using a Base 36 numbering system employing both numerals and letters. These two-number sets start with 00, 01, 02, 03, 04, 05, 06, 07, 08, 09, OA, OB ... 0Z, followed by 10-1Z, 20-2Z, etc.

The CID number appears on each page of the manuscript. The complete citation is used on the first page, and an abbreviated version on subsequent pages. 
641409 A novel strain sensor using carbon nanotubes-organic semiconductor matrix composite on polymeric substrates (Invited Paper) [6414-10]

S. Jung, T. Ji, J. Xie, V. K. Varadan, The Univ. of Arkansas (USA)

64140B Optimization of integrated antennas for wireless sensors [6414-12]

A. Gandelli, M. Mussetta, R. E. Zich, Politecnico di Milano (Italy)

64140C Thin metal foil sensors [6414-13]

A. Wilson, P. McMahon, R. Muscat, O. Vargas, P. Vincent, Defence Science and Technology Organisation (Australia)

64140D Potential system efficiencies for MEMS vibration energy harvesting [6414-14]

S. Behrens, CSIRO (Australia)

\section{SESSION 4 POLYMERS/PZT}

$64140 E$ Modeling of a fluid-filled ionic polymer-metal composite cylindrical shell (Invited Paper) [6414-15]

L. Zhang, Y. Yang, Nanyang Technological Univ. (Singapore)

\section{SESSION 5 PHOTONIC/THZ}

$64140 \mathrm{H}$ Integrated broadband microphotonic beamformer for adaptive nulling in smart antennas (Invited Paper) [6414-19]

B. Juswardy, K. Alameh, Edith Cowan Univ. (Australia); Y. T. Lee, Gwangju Institute of Science and Technology (South Korea)

64140I Microwire fibers for low-loss THz transmission [6414-20]

S. Atakaramians, S. Afshar Vahid, B. M. Fischer, H. Ebendorff-Heidepriem, T. Monro,

D. Abbott, The Univ. of Adelaide (Australia)

64140J Opto-VLSI-based reconfigurable free-space optical interconnects architecture [6414-21] M. Aljada, K. E. Alameh, Edith Cowan Univ. (Australia); Y.-T. Lee, I.-S. Chung, Gwangju Institute of Science and Technology (South Korea)

64140K Design and optimization of programmable lens array for adaptive optics [6414-22] Z. Wang, S. H. Eng, K. Alameh, Edith Cowan Univ. (Australia)

64140L Review of THz near-field methods [6414-23]

H. Lin, B. M. Fischer, S. P. Mickan, D. Abbott, The Univ. of Adelaide (Australia)

\section{SESSION 6 DEVICES}

$64140 \mathrm{~N}$ Template synthesis of nano- and micro-resonant tunneling diodes [6414-25]

S. K. Chakarvarti, National Institute of Technology, Deemed Univ. (India)

641400 Fuzzy control of shear-mode MR damper under impact force [6414-26]

J. Cho, H. Y. Kim, T. Jung, J. Joh, Changwon Univ. (South Korea) 
64140P Development of a mechanical mover device by compositing hydrogen storage alloy thin films with a perfluorosulfonic acid layer [6414-27]

T. Ogasawara, H.-H. Uchida, Y. Nishi, Tokai Univ. (Japan)

64140 Electro-acoustic and acousto-optic communications for robotic agents in smart structures [6414-28]

G. Wild, S. Hinckley, Edith Cowan Univ. (Australia)

SESSION 7 ACTUATORS II

$64140 S$ Fabrication of various metal electrodes on the electro-active paper actuators using soft lithography [6414-31]

H. G. Lim, J. Kim, K. S. Kang, Inha Univ. (South Korea)

64140T Magnetic actuation for microfluidics based on ferrofluid droplets [6414-32]

N.-T. Nguyen, K. M. Ng, X. Huang, Nanyang Technological Univ. (Singapore)

$64140 \mathrm{U}$ Improving the security and actuation of wireless controlled microvalve [6414-33]

A. C. Tikka, S. Al-Sarawi, D. Abbott, M. S. K. Wong, J. D. Schutz, Univ. of Adelaide (Australia)

SESSION 8 STRUCTURES MONITORING

$64140 \mathrm{~W}$ Health assessment of bonded composite repairs with frequency response techniques

[6414-42]

C. White, Royal Melbourne Institute of Technology Univ. (Australia); B. Whittingham, Monash Univ. (Australia); H. C. H. Li, Royal Melbourne Institute of Technology Univ. (Australia);

I. Herszberg, Cooperative Research Ctr. for Advanced Composite Structures Ltd.

(Australia); A. P. Mouritz, Royal Melbourne Institute of Technology Univ. (Australia)

64140X Influence of loading on structures actuated with piezoceramic transducers [6414-37]

V. G. M. Annamdas, Y. Yang, C. K. Soh, Nanyang Technological Univ. (Singapore)

$64140 Y$ Design architecture for multi-zone HVAC control systems from existing single-zone systems using wireless sensor networks [6414-38]

A. Redfern, M. Koplow, P. Wright, Univ. of California at Berkeley (USA)

SESSION 9 ANALOG/DIGITAL CIRCUITS

$64140 Z$ A small low-power networked and versatile sensor interface (Invited Paper) [6414-39] P. S. Vincent, P. J. McMahon, R. F. Muscat, Defence Science and Technology Organisation (Australia); L. Zeve, Boeing Australia Ltd., DSTO (Australia); A. R. Wilson, Defence Science and Technology Organisation (Australia)

641411 An open source synthesisable model in VHDL of a 64-bit MIPS-based processor [6414-41] D. R. Kelly, B. J. Phillips, S. Al-Sarawi, The Univ. of Adelaide (Australia)

641412 A data management layer for parallel matrix computation [6414-43]

A. Burdeniuk, K. To, C. C. Lim, The Univ. of Adelaide (Australia) 
641413 Optimal configurations of active fiber composites based on asymptotic torsional analysis [6414-45]

D. Harursampath, A. K. Tamrakar, Indian Institute of Science (India)

641414 Macro-fiber composite (MFC) as a delamination sensor in antisymmetric laminates [6414-46]

S. Hari Krishna, Vikram Sarabhai Space Ctr. (India); D. Harursampath, Indian Institute of Science (India)

641415 Study on micro-bend light transmission performance of novel liquid-core optical fiber [6414-48]

J. Ma, Nanjing Univ. of Aeronautics and Astronautics (China) and Qingdao Univ. (China);

Z. Zhao, K. Wang, L. Guo, Nanjing Univ. of Aeronautics and Astronautics (China)

\section{SESSION 11 IMAGERS AND VISION}

641416 Bio-inspired pixel-wise adaptive imaging [6414-49]

R. S. A. Brinkworth, E.- L. Mah, D. C. O'Carroll, The Univ. of Adelaide (Australia)

641417 MOEMS development of infrared security sensors [6414-51]

K. C. Liddiard, Electro-optic Sensor Design (Australia)

641418 Bio-inspired optical rotation sensor [6414-52]

D. C. O'Carroll, Univ. of Adelaide (Australia); P. A. Shoemaker, Tanner Research Inc. (USA);

R. S. A. Brinkworth, Univ. of Adelaide (Australia)

\section{SESSION 12 PROCESS/TECHNOLOGY}

641419 MEMS design synthesis: integrating case-based reasoning and multi-objective genetic algorithms (Invited Paper) [6414-53]

C. L. Cobb, Univ. of California at Berkeley (USA); Y. Zhang, Georgia Institute of Technology (USA); A. M. Agogino, Univ. of California at Berkeley (USA)

64141A Response improvement of a mover device using hydrogen storage alloy powder by addition of catalyst [6414-54]

A. Sato, K. Akazawa, T. Ogasawara, H.- H. Uchida, Y. Nishi, Tokai Univ. (Japan)

64141B Nickel silicide and titanium silicide formation: a comparison [6414-55]

M. Bhaskaran, S. Sriram, A. S. Holland, J. du Plessis, RMIT Univ. (Australia)

\section{SESSION 13 POSTER SESSION}

64141D Prototype ROIC with differential pixel readout for uncooled IR detector arrays [6414-50] S. J. Hwang, S. W. Ryu, H. H. Shin, M. Y. Sung, Korea Univ. (South Korea) 
$64141 \mathrm{~F}$ A reconfigurable photonic bandpass RF filter employing a semiconductor optical amplifier and an opto-VLSI processor [6414-61]

R. Zheng, K. Alameh, Edith Cowan Univ. (Australia); Y. T. Lee, Gwangju Institute of Science and Technology (South Korea); Z. Wang, Edith Cowan Univ. (Australia)

$64141 \mathrm{G}$ Thin silicon shadow masks for organic light-emitting diodes (OLED) deposition processes [6414-62]

C.-C. Tseng, C.-C. Chiu, K.-X. Zhung, J.-H. Lee, G.-D. J. Su, National Taiwan Univ. (Taiwan)

$64141 \mathrm{H} \quad$ Fabrication of high-aspect-ratio coil for electromagnetic actuators using LIGA process [6414-63]

D. Noda, Y. Matsumoto, S. Yamashita, M. Setomoto, T. Hattori, Univ. of Hyogo (Japan)

641411 A novel photoelectric system for optical intelligent structure health monitoring [6414-64] Z. Zhao, L. Guo, Y. Hou, J. Ma, K. Wang, Nanjing Univ. of Aeronautics and Astronautics (China)

$64141 \mathrm{~J}$ The effect of structure perturbation on PBG of one-dimensional photonic crystals [6414-65] X. Li, Y. Jiang, W. Xue, Z. YU, H.-Q. Wang, Beijing Institute of Technology (China)

$64141 \mathrm{~K}$ Multi-wavelength oscillation DFB solid-state dye laser with cascade-arranged gratings [6414-66]

N. Nakai, M. Fukuda, Chitose Institute of Science and Technology (Japan)

$64141 \mathrm{~L}$ Fabrication of gratings with moire fringes and their application to solid-state dye laser [6414-67]

K. Miura, M. Fukuda, Chitose Institute of Science and Technology (Japan)

$64141 \mathrm{~N}$ Tunable properties of dielectrics thick film added $\mathrm{MgO}$ and $\mathrm{Li}_{2} \mathrm{CO}_{3}$ to $\mathrm{BST}$ [6414-70] I. S. Kim, S. J. Jeong, B. K. Min, J. S. Song, Korea Electrotechnology Research Institute (South Korea); S. H. Jeon, Kyungnam Univ. (South Korea)

64141P Calibration of wavelength shift for a fibre Bragg grating using a single mode laser source [6414-72]

H. Ji, A. B. Wedding, L. X. Kong, H. Y. Hsu, G. C. I. Lin, Univ. of South Australia (Australia);

K. C. Fan, National Taiwan Univ. (Taiwan)

$64141 \mathrm{Q}$ Camphor sulfonic acid-doped polyaniline nanofiber-based $64^{\circ} \mathrm{YX} \mathrm{LiNbO}_{3} \mathrm{SAW}$ hydrogen gas sensor [6414-73]

W. Wlodarski, A. Z. Sadek, RMIT Univ. (Australia); C. Baker, Univ. of California, Los Angeles (USA); K. Kalantar-zadeh, RMIT Univ. (Australia); R. B. Kaner, Univ. of California, Los Angeles (USA); D. Mulcahy, Univ. of South Australia (Australia)

$64141 \mathrm{R}$ Modelling of coplanar waveguide transmission lines in multiple metal layer processes [6414-74]

E. Heading, Flinders Univ. (Australia); H. J. Hansen, M. E. Parker, Defence Science and Technology Organisation (Australia)

64141S Motion detection with a view toward VLSI implementation [6414-75]

X. J. Tan, S. Chong, T. Rainsford, S. Al-Sarawi, The Univ. of Adelaide (Australia) 
$64141 \mathrm{~T}$ The effect of inter-pixel nested ridges incorporated in a stacked gradient homojunction photodiode architecture [6414-76]

P. V. Jansz, S. Hinckley, Edith Cowan Univ. (Australia)

$64141 \mathrm{U}$ Terahertz detection of substances for security related purposes [6414-77]

B. Ung, J. Balakrishnan, B. Fischer, B. W.-H. Ng, D. Abbott, The Univ. of Adelaide (Australia)

64141V Grooved infrared polarizers with a reduced reflectance [6414-78]

I. Yamada, Ryukoku Univ. (Japan); J. Nishii, National Institute of Advanced Industrial

Science and Technology (Japan); M. Saito, Ryukoku Univ. (Japan)

64141W Optimised MEMS-based reconfigurable VCO for a mobile receiver [6414-80]

H. P. Le, J. Singh, La Trobe Univ. (Australia)

64141Y Development of a tendon driven system using a pneumatic balloon [6414-82]

R. Sato, J. Nagase, N. Saga, S. Chonan, Akita Prefectural Univ. (Japan)

641412 A compact optical fiber scanner for medical imaging [6414-83]

N. Dhaubanjar, H. Hu, D. Dave, P. Phuyal, J. Sin, H. Stephanou, J.-C. Chiao, The Univ. of Texas at Arlington (USA)

641420 Investigation of vertical displacement thermal actuators [6414-84]

N. Dhaubanjar, S. M. N. Rao, H. Lun-Chen, M. Luquire, D. Popa, The Univ. of Texas at Arlington (USA); M. Chiao, The Univ. of British Columbia (Canada); H. Stephanou,

J.-C. Chiao, The Univ. of Texas at Arlington (USA)

641421 A cantilever-type electrostatic zipping actuator [6414-85]

N. Dhaubanjar, S. M. N. Rao, Y. Cai, D. Popa, The Univ. of Texas at Arlington (USA); M. Chiao, The Univ. of British Columbia (Canada); J.-C. Chiao, The Univ. of Texas at Arlington (USA)

641422 An RNS public key cryptography accelerator [6414-86] T. A. Coleman, J. A. Kitchener, D. L. Pudney, K. D. Wauchope, B. J. Phillips, The Univ. of Adelaide (Australia)

641423 Control performance of pneumatic artificial muscle [6414-87]

N. Saga, S. Chonan, Akita Prefectural Univ. (Japan)

641424 Implementation of saturation for modelling pattern noise using naturalistic stimuli [6414-88] S. Rajesh, T. Rainsford, R. S. A. Brinkworth, D. Abbott, D. C. O'Carroll, The Univ. of Adelaide (Australia)

641425 An active locking mechanism for assembling 3D micro structures [6414-89] P. Zhang, M. Mayyas, W. H. Lee, D. Popa, P. Shiakolas, H. Stephanou, J. C. Chiao, The Univ. of Texas at Arlington (USA)

641426 Experimental comparisons between McKibben type artificial muscles and straight fibers type artificial muscles [6414-90]

T. Nakamura, Chuo Univ. (Japan)

Author Index 


\title{
Conference Committee
}

\author{
Symposium Chairs
}

Joe G. Shapter, Flinders University (Australia)

Vijay K. Varadan, University of Arkansas (USA)

Derek Abbott, The University of Adelaide (Australia)

Conference Chair

Said F. Al-Sarawi, The University of Adelaide (Australia)

Cochairs

Vijay K. Varadan, University of Arkansas (USA)

Neil H. E. Weste, NHEW R\&D Pty Ltd. (Australia)

Program Committee

Derek Abbott, The University of Adelaide (Australia)

Kamal Alameh, Edith Cowan University (Australia)

Mahmoud A. Al-Qutayri, Etisalat University College (United Arab Emirates)

Subhas Basu, Silicon Interfaces (India)

Abdesselam S. Bouzerdoum, University of Wollongong (Australia)

Robert G. Clark, University of New South Wales (USA)

Sorin D. Cotofana, Technische Universiteit Delft (Netherlands)

Bernard Courtois, TIMA Laboratory (France)

Paul D. Franzon, North Carolina State University (USA)

Manfred Glesner, Technische Universität Darmstadt (Germany)

Hedley J. Hansen, Defence Science and Technology Organisation

(Australia)

Sung-Mo Kang, University of California/Santa Cruz (USA)

Chee Yee Kwok, University of New South Wales (Australia)

Stefan W. Lachowicz, Edith Cowan University (Australia)

Kevin C. Liddiard, Electro-optic Sensor Design (Australia)

Michael Liebelt, The University of Adelaide (Australia)

Warren Marwood, Defence Science and Technology Organisation

(Australia)

Alireza Moini, Silverbrook Research Pty. Ltd. (Australia)

Ampalavanapillai Nirmalathas, The University of Melbourne (Australia)

Saeid Nooshabadi, University of New South Wales (Australia)

Adam Osseiran, Edith Cowan University (Australia)

Dimitris Pavlidis, University of Michigan (USA)

Richard Perks, Cardiff University (United Kingdom)

Braden J. Phillips, The University of Adelaide (Australia)

Jugdutt J. Singh, La Trobe University (Australia)

David V. Thiel, Griffith University (Australia) 
Session Chairs

Actuators 1

Said F. Al-Sarawi, The University of Adelaide (Australia)

Radio Frequency

Michael Liebelt, The University of Adelaide (Australia)

Sensors

Vijay K. Varadan, University of Arkansas (USA)

Polymers/PZT

Kevin C. Liddiard, Electro-optic Sensor Design (Australia)

Photonic/THz

Hedley J. Hansen, Defence Science and Technology Organisation (Australia)

Devices

Said F. Al-Sarawi, The University of Adelaide (Australia)

Actuators II

Said F. Al-Sarawi, The University of Adelaide (Australia)

Structures Monitoring

Olaf Reinhold, Defence Science and Technology Organisation (Australia)

Analog/Digital Circuits

Braden J. Phillips, The University of Adelaide (Australia)

Fibers

Rong Zheng, Edith Cowan University (Australia)

Imagers and Vision

Brian Ng, The University of Adelaide (Australia)

Process/Technology

Said F. Al-Sarawi, The University of Adelaide (Australia) 


\section{Introduction}

The Smart Structures, Devices, and Systems conference was part of SPIE's 2006 Symposium on Smart Materials, Nano- and Micro-Smart Systems III held at the University of Adelaide, Adelaide, Australia. Four other parallel conferences were held as part of this symposium: Smart Materials IV, Micro- and Nanotechnology III, Biomedical Applications of Micro- and Nanoengineering III, and Complexity and Nonlinear Dynamics.

The papers in these proceedings represent some of the latest research issues in the field of smart structures that are used for devices and systems implementation. The presented research covered a broad spectrum of topics such actuators, polymers, PZT, photonics, sensors, structure monitoring, and fibers. Due to the great demand in this conference for oral presentations, two parallel sessions were set up the first day. This seemed to be popular with the delegates and the authors.

The conference chair and co-chairs would like to thank the symposium chairs, Joe Shapter (Flinders University), Vijay K. Varadan (University of Arkansas), and Derek Abbott (The University of Adelaide), for their superb work and effort.

Special thanks are due to the plenary speakers: Peter Hanggi "Brownian Motion Reigning Manipulation and Transport on the Nanoscale," Benjamin Eggleton "Microphotonics for Signal Processing, Microfluidics and Sensing Applications," Hywel Morgan "Microfluidic Analytical Systems for High-Throughput Multiplexed Bio-assays," Vijay Varadan "The Role of Nanotechnology and Monitoring and Control of Cardiovascular Diseases and Neurological Disorders," and Barry LutherDavies "All Optical Processing for Advanced Communications Systems." These speakers did a wonderful job in setting the scene for the conference.

Special thanks are due to SPIE staff for their very professional organization of this conference. All the hard work producing the materials, managing the website, liaising with conference chairs, co-chairs, and participants was done by the SPIE, thus considerably lightening the load for the Chairs and Committee to get research outcomes to the research communities in a timely matter. The committee members of this conference must also be thanked for their excellent support and labors. Finally, our appreciation must go to all the delegates for sharing their research, vision, enthusiasm, and stimulating questions. The resulting interaction made this a very vibrant conference. 
In order to comply with the requirements of some institutions, the authors were able to have their full manuscripts peer-reviewed by the international conference committee listed in these proceedings.

Said F. Al-Sarawi Vijay K. Varadan Neil H. E. Weste 


\section{Major Co-sponsor}

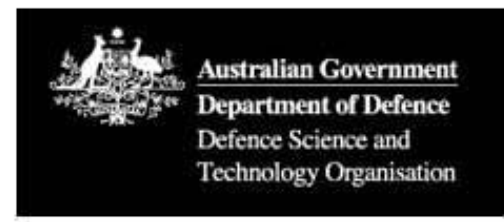

\section{Co-sponsors}
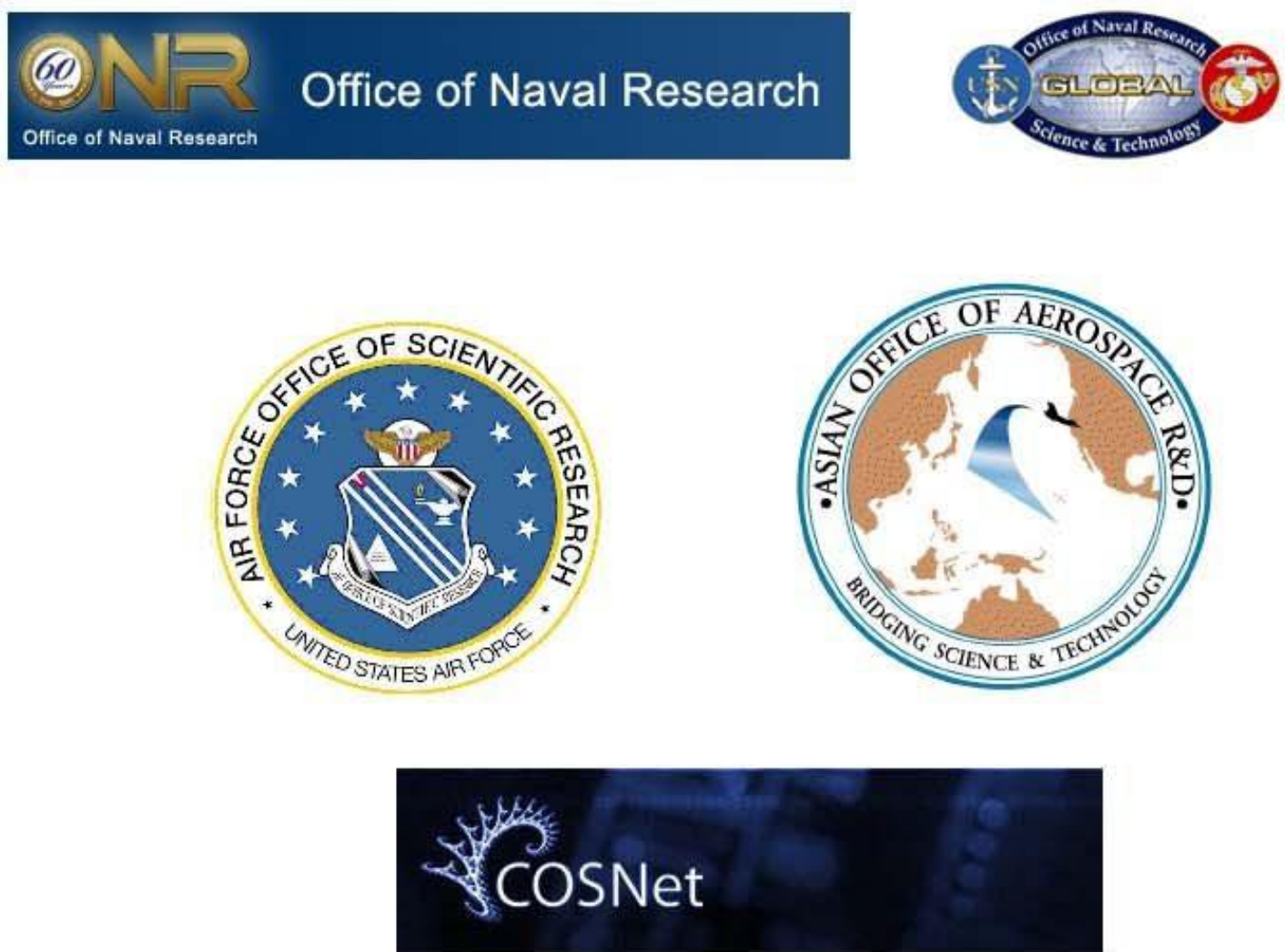

ARC Complex Open Systems Research Network

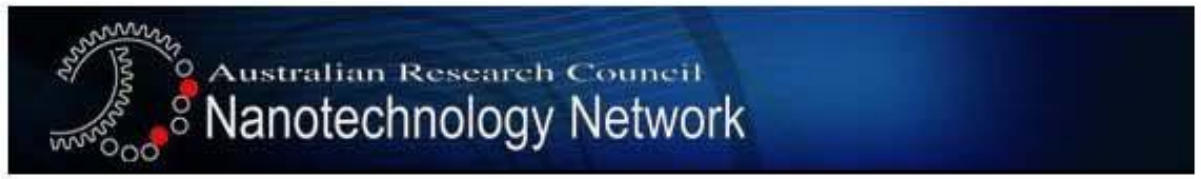

We wish to thank the co-sponsors for their contribution to the success of the conference:

Defence Science and Technology Organisation (DSTO)

Air Force Office of Scientific Research, Asian Office of Aerospace Research and Development

Office of Naval Research Global

ARC Complex Open Systems Research Network

ARC Nanotechnology Network 
Downloaded From: https://www.spiedigitallibrary.org/conference-proceedings-of-spie on 26 Apr 2023

Terms of Use: https://www.spiedigitallibrary.org/terms-of-use 